\title{
Effect of Nutrient Combinations on Plant Pigments and Yield of Bt Cotton Under Rainfed Condition
}

\author{
N.A. Byale ${ }^{1 *}$, V.D. Patil ${ }^{1}$ and B.M. Nandede ${ }^{2}$ \\ ${ }^{1}$ College of Agriculture, Vasantrao Naik Marathwada Krishi Vidyapeeth, Parbhani, India \\ ${ }^{2}$ ICAR-Central Institute of Agricultural Engineering, Bhopal, India \\ *Corresponding author
}

\author{
A B S T R A C T
}

\section{Keywords \\ Cotton, nutrient combinations, soil application, total chlorophyll, anthocyanin}

\section{Article Info}

Accepted: 07 September 2017 Available Online: 10 November 2017
An experiment was conducted to reveal the effect of nutrients combinations on plant pigments and yield in Bt cotton under rainfed condition in kharif season of 2011-2012. The experiment was laid out in randomized block design with ten treatments $\left(\mathrm{T}_{1}\right.$ to $\left.\mathrm{T}_{10}\right)$ replicated thrice. Data on total chlorophyll, anthocyanin and dry matter yield at square formation, boll development, boll bursting and harvest stage whereas the seed cotton yield at harvest stage was collected and analysed. It was found that the chlorophyll and anthocyanin content, dry matter yield and seed cotton yield were influenced by nutrient combinations. Total chlorophyll content in leaves was highest with nutrient combination of $\mathrm{T}_{9}$ (Recommended dose of nitrogen + phosphorus + potassium + sulphur + magnesium + zinc +boron spray). Among all the nutrient combinations the highest anthocyanin content was found in $T_{1}$ (control) and lowest anthocyanin content was observed in $T_{8}$ (Recommended dose of nitrogen + phosphorus + potassium + sulphur + magnesium + zinc) followed by $\mathrm{T}_{9}$. Therefore, $\mathrm{T}_{8}$ and $\mathrm{T}_{9}$ was found to be preventive for cotton reddening than $\mathrm{T}_{10}$ [Recommended dose for Bt cotton $(125: 62.5: 62.5)+\mathrm{S}$ ] and $\mathrm{T}_{1}$. Highest dry matter yield 179.2 plant $^{-1}$ followed by $177.3 \mathrm{~g}$ plant $^{-1}$ was recorded with $\mathrm{T}_{10}$ and $\mathrm{T}_{9}$, respectively. $\mathrm{T}_{10}$ produced highest $19.22 \mathrm{q} \mathrm{ha}^{-1}$ followed by $\mathrm{T}_{9}$ with $19.04 \mathrm{q} \mathrm{ha}^{-1}$ seed cotton yield. Therefore, considering plant pigments yield, $\mathrm{T}_{9}$ can be recommended for growing of $\mathrm{Bt}$ cotton under rainfed condition.

\section{Introduction}

Cotton is the most important commercial crop of India and popularly known as "White Gold" (Bharambe, 2010). It is has a national significance as its immense influence on Indian economy. It is grown as a source of food, fiber and fuel. India occupies top most position among the cotton growing countries of the world. However, India ranks third in terms of production and productivity (CCI, 2011). To raise the level of income, high yielding varieties like $\mathrm{Bt}$ cotton are being mostly cultivated by Indian farmers Reduction in yield of cotton is due to several factors, leaf reddening by abiotic stress related to disturbed soil ion equilibrium leading to potassium shortage and accumulation of sodium ions in cotton leaves (Koleva et al., 2005). Being an important crop, cotton is largely studied in respect to abiotic stress constraint such as nutrient deficiency, salinity and high temperature etc. However very little information is available 
on leaf reddening in cotton. It certainly affects the dry matter yield and seed cotton yield. Therefore, this study was aimed to reveal the effect of different nutrients combinations on total chlorophyll, anthocyanin contents, dry matter yield and seed cotton yield in Bt cotton under rainfed condition

\section{Materials and Methods}

A field experiment was conducted on experimental farm of Department of Soil Science and Agricultural Chemistry, VNMKV, Parbhani, during kharif 2011-2012. The experiment was laid out in Randomized Block Design (RBD) with ten treatments and three replications. The $\mathrm{Bt}$ cotton variety Rasi 2 was sown 30 plots of size $4.8 \mathrm{~m} \mathrm{x} 4.2 \mathrm{~m}$ each. The seeds were dibbled at the spacing of $60 \times 60 \mathrm{~cm}$ check row planting. The experimental site was slightly alkaline, medium in organic carbon, non-calcareous in nature, low in available $\mathrm{N}\left(136 \mathrm{Kg} \mathrm{ha}^{-1}\right)$ and $\mathrm{P}$ $\left(7.8 \mathrm{Kg} \mathrm{ha}^{-1}\right)$, high in available $\mathrm{K}\left(629 \mathrm{Kg} \mathrm{ha}^{-}\right.$ $\left.{ }^{1}\right)$, low in available Sulphur with sufficient available micronutrients. The dose of nitrogen, phosphorus, potassium, sulphur and zinc, were applied in soil at the time of sowing.

The $\mathrm{Zn}$ and Boron were applied through $\mathrm{ZnSO}_{4}$ and borax, respectively. The quantity and source of fertilizer for each plot was calculated on the basis of recommended dose and is given in Table 1. Details of the treatments used to conduct the experiment are given in Table 2.

The leaves were collected at square formation, boll development and boll bursting stages. Di-Methyle Sulphoxide (DSMO) extraction technique by Hiscox and Israelstam (1979) was used for chlorophyll extraction and total chlorophyll content was determined as described by Arnon (1975). The amount of Anthocyanin pigment was determined spectrophotometrically following Thimmaiah (2004). Dry matter yield was recorded at square formation, boll development, boll bursting and harvest stages of the crop. The weight of dry matter accumulated in plant is an index of plant growth. For dry matter determination the plants were air dried under sun for eight days and subsequently dried in oven at the temperature $80^{\circ} \mathrm{c}$ for 12 hours. The final constant dry weight was recorded as total dry matter accumulation per plant. Three pickings of cotton were done after 160 and 178 days of sowing. The yield seed cotton yield per hectare was calculated by weighing cotton picked per plot in $\mathrm{kg}$ divided by its area in hectare. The total chlorophyll content, anthocyanin, dry matter yield and seed cotton yield was statistically analyzed for Mean, standard error (SE) and critical differences (CD) at 5\% level as described by Panse and Sukhatme (1967).

\section{Results and Discussion}

\section{Effect of nutrient application on total chlorophyll content}

Effect of nutrient application on total chlorophyll content is shown in Figure 1. The treatment $\mathrm{T}_{9}$ showed highest chlorophyll content $3.25,3.53$ and $3.42 \mathrm{mg} \mathrm{g-}{ }^{1}$ at square formation, boll development and boll bursting stages, respectively. The total chlorophyll content significantly decreased in all other treatments. This may be due to the supply of nitrogen, boron, $\mathrm{Mn}$ and $\mathrm{Zn}$. The treatment $\mathrm{T}_{2}$ showed drastic reduction in chlorophyll content $1.75 \mathrm{mg} \mathrm{g-}{ }^{1}$ and it was at par with control. Mean, SE and CD at 5\% level for total chlorophyll content at square formation, boll development and boll bursting were 2.34, $0.14,0.43 ; 2.650 .14,0.41$, and 2.22, 0.19, 0.58 , respectively. Similar findings were reported by Jadhao, et al., (2004), Patil and Malewar (1994) and Jaylalitha and Narayanan (1996). 
Effect of nutrient application on Anthocyanin

Effect of nutrient application on anthocyanin content is shown in Figure 2. Highest anthocyanin content of $4.87 \mathrm{mg} \mathrm{g-}{ }^{1}$ was observed at square formation stage in treatment $\mathrm{T}_{1}$ and significantly decreased up to $3.59 \mathrm{mg} / \mathrm{g}$ in $\mathrm{T}_{2}$. The anthocyanin content reduced in all other treatments. The finding on anthocyanin pigment at same stage was observed by Perumal and Subramanian (1979) and Chimmad et al., (1997). However, it increased at boll bursting stage in all treatments. Anthocyanin increased as crop reaches to maturity. The anthocyanin pigment significantly reduced in all other treatments and minimum anthocyanin content was recorded in plants grown in $\mathrm{T}_{8}$ and at par with $\mathrm{T}_{9}$. The high content of anthocyanin pigment at boll bursting stage was also reported by Zade and Dhopte (1987). Total chlorophyll content in leaves was highest in $\mathrm{T}_{9}$. Mean, SE and $\mathrm{CD}$ at $5 \%$ level for anthocyanin content at square formation, boll development and boll bursting were $2.24,0.24,0.72 ; 14.85,0.8,2.38$ and $026.62,1.58,4.69$, respectively. Among all the nutrient combinations and growth stages, highest anthocyanin content was observed in
$\mathrm{T}_{1}$ whereas lowest anthocyanin was recorded in $\mathrm{T}_{8}$ and at par with $\mathrm{T}_{9}$. Therefore, $\mathrm{T}_{8}$ and $\mathrm{T}_{9}$ were found to be more preventive for cotton reddening than $T_{10}$ and $T_{1}$.

\section{Effect of nutrient yield on dry matter yield}

Figure 3 shows the effect of nutrient application on dry matter yield. Dry matter yield at all treatments were varied from 21.36-27.9; 136.5-145.2; $152.2-171.7$ and 161.3-179.1 $\mathrm{g} \mathrm{plant}^{-1}$ at square formation, boll development, boll bursting and harvest stage, respectively. $\mathrm{T}_{10}$ produced highest dry matter of $179.2 \mathrm{~g} \mathrm{plant}^{-1}$ followed by $177.3 \mathrm{~g} \mathrm{plant}^{-1}$ with $\mathrm{T} 9$ at boll harvest stage. The dry matter production decreased significantly in all other treatments and stages. Mean, SE and CD at $5 \%$ level for dry matter yield at square formation, boll development, boll bursting and at harvest stage were $25.16,0.44,1.33$; $142.01,0.27,0.81 ; 162.81,1.01,3.01$ and $171.25,0.57,1.71$, respectively. Dry matter production was found increased with increase in age of the plant and nutrients. Findings were supported by Ramalakhmi and Anthoni Raj (2008), Rao and Janawade, (2006) and Gurao et al., (2006).

Table.1 Quantity and source of fertilizers application

\begin{tabular}{lllll}
\hline Treatment. No. & $\begin{array}{l}\text { Nutrients } \\
\text { applied }\end{array}$ & $\begin{array}{l}\text { Quantity } \\
\left(\mathrm{Kg} \mathrm{ha}^{-1}\right)\end{array}$ & Source of nutrient & $\begin{array}{l}\text { Quantity of sources }(\mathrm{g} \\
\left.\text { plot }^{-1}\right)\end{array}$ \\
\hline $\mathrm{T}_{1}$ & - & - & - & - \\
$\mathrm{T}_{2}$ & $\mathrm{P}+\mathrm{K}$ & $40+40$ & SSP+MOP & $503+137$ \\
$\mathrm{~T}_{3}$ & $\mathrm{~N}+\mathrm{K}$ & $80+40$ & Urea $+\mathrm{MOP}$ & $345+137$ \\
$\mathrm{~T}_{4}$ & $\mathrm{~N}+\mathrm{P}$ & $80+40$ & Urea $+\mathrm{SSP}$ & $345+503$ \\
$\mathrm{~T}_{5}$ & $\mathrm{~N}+\mathrm{P}+\mathrm{K}$ & $80+40+40$ & Urea+SSP+MOP & 282 \\
$\mathrm{~T}_{6}$ & $\mathrm{~N}+\mathrm{P}+\mathrm{K}+\mathrm{S}$ & $80+40+40+30$ & $\begin{array}{l}\text { Urea+SSP+MOP+Elemental } \\
\text { sulphur }\end{array}$ & $345+503+137+50.5$ \\
$\mathrm{~T}_{7}$ & $\mathrm{~N}+\mathrm{P}+\mathrm{K}+\mathrm{S}+\mathrm{Mg}$ & $80+40+40+30$ & $\begin{array}{l}\text { Urea+SSP+MOP+Elemental } \\
\text { sulphur+MgSO }\end{array}$ & $345+303+137+50.5$ \\
$\mathrm{~T}_{8}$ & $\mathrm{~N}+\mathrm{P}+\mathrm{K}+\mathrm{S}+$ & $80+40+40+30$ & $\begin{array}{l}\text { Urea+SSP+MOP+Elemental } \\
\text { sulphur+MgSO }+\mathrm{ZnSO}_{4}\end{array}$ & $345+303+137+50.5$ \\
$\mathrm{~T}_{9}$ & $\mathrm{Mg}+\mathrm{Zn}$ & & Urea+SSP+MOP+Elemental & $345+303+137+50.5$ \\
$\mathrm{~T}_{10}$ & $\mathrm{~N}+\mathrm{P}+\mathrm{K}+\mathrm{S}+$ & $80+40+40+30$ & $\begin{array}{l}\text { sulphur }+\mathrm{MgSO}_{4}+\mathrm{ZnSO}_{4}+\text { Borax } \\
\text { Urea+SSP+MOP+Elemental ulphur }\end{array}$ & $546+787+787+50.5$ \\
\hline
\end{tabular}


Table.2 Details of treatment

\begin{tabular}{ll}
\hline Symbol & Treatment \\
\hline $\mathrm{T}_{1}$ & Control \\
$\mathrm{T}_{2}$ & Recommended dose of phosphorus + Potassium. \\
$\mathrm{T}_{3}$ & Recommended dose of nitrogen + potassium \\
$\mathrm{T}_{4}$ & Recommended dose of nitrogen + phosphorus \\
$\mathrm{T}_{5}$ & Recommended dose of nitrogen + phosphorus + potassium \\
$\mathrm{T}_{6}$ & Recommended dose of nitrogen + phosphorus + potassium + sulphur \\
$\mathrm{T}_{7}$ & Recommended dose of nitrogen + phosphorus + potassium + sulphur + \\
& magnesium $(1 \%-2$ spray) \\
$\mathrm{T}_{8}$ & Recommended dose of nitrogen + phosphorus + potassium + sulphur + \\
& magnesium + zinc \\
$\mathrm{T}_{9}$ & Recommended dose of nitrogen + phosphorus + potassium + sulphur + \\
& magnesium + zinc +boron (spray) \\
$\mathrm{T}_{10}$ & Recommended dose for Bt cotton.(125:62.5:62.5)+S \\
\hline
\end{tabular}

Fig.1 Effect of nutrient application on total chlorophyll content

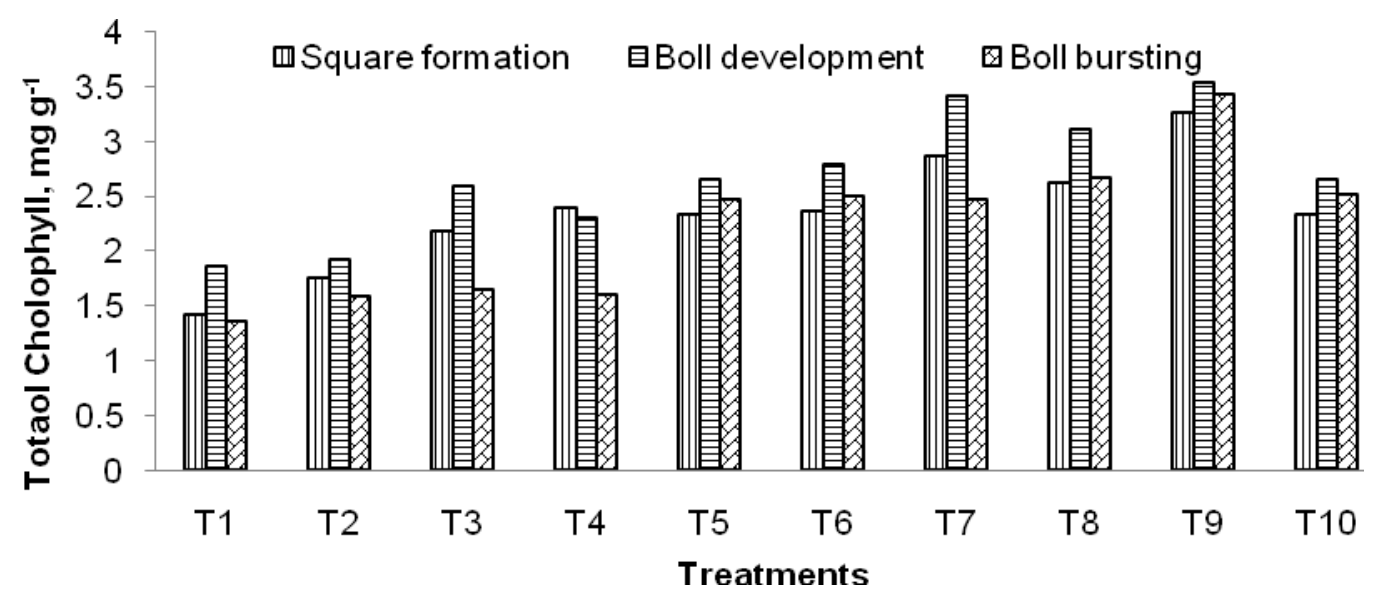

Fig.2 Effect of nutrient application on anthocyanin content

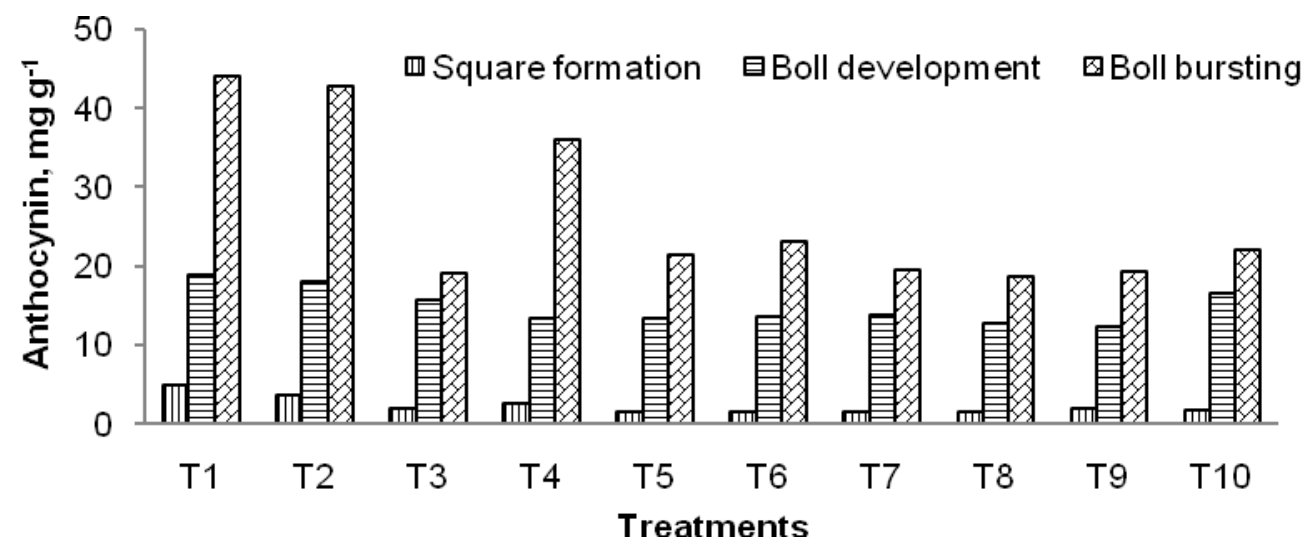


Fig.3 Effect of nutrient application on dry matter yield



Fig.4 Effect of nutrient application on seed cotton yield

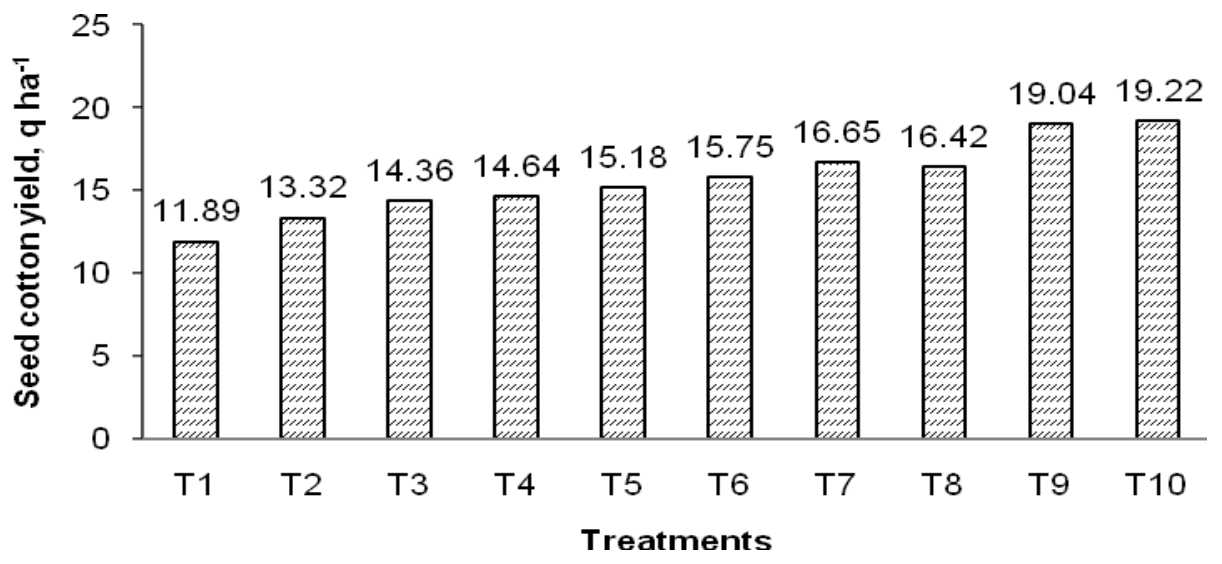

Effect of fertilizer application on seed cotton yield

Highest seed cotton yield $19.22 \mathrm{q} \mathrm{ha}^{-1}$ was recorded in $\mathrm{T}_{10}$ followed by $\mathrm{T}_{9}$ with about $1 \%$ reduction in yield than $T_{10}$. The seed cotton yield was further decreased significantly up to $16.65,16.42,15.75$ and $15.18 \mathrm{q} \mathrm{ha}^{-1}$ in treatments $\mathrm{T}_{8}, \mathrm{~T}_{7}, \mathrm{~T}_{6}$ and $\mathrm{T}_{5}$, respectively. Considerable decrease in yield was observed in $\mathrm{T}_{4}, \mathrm{~T}_{3}$ and $\mathrm{T}_{2}$ whereas; lowest yield $11.89 \mathrm{q}$ $\mathrm{ha}^{-1}$ was obtained in control. Mean, SE and $\mathrm{CD}$ at 5\% level for seed cotton yield at harvest stage were $15.65,14.45$ and $42.94 \mathrm{q}$ $\mathrm{ha}^{-1}$ respectively. Effect of nutrient application on seed cotton yield is shown in Figure 4.
Total chlorophyll content in leaves was highest with nutrient combination of $\mathrm{T}_{9}$. Among all the nutrient combinations the highest content of anthocyanin were found in $\mathrm{T}_{1}$ and lowest anthocyanin content was observed in $\mathrm{T}_{8}$ followed by $\mathrm{T}_{9}$.

Therefore, $\mathrm{T}_{8}$ and $\mathrm{T}_{9}$ were found to be preventive for cotton reddening than $\mathrm{T}_{10}$ and $\mathrm{T}_{1}$. Highest dry matter yield $179.2 \mathrm{~g} \mathrm{plant}^{-1}$ followed by $177.3 \mathrm{~g} \mathrm{plant}^{-1}$ was recorded with $\mathrm{T}_{10}$ and $\mathrm{T}_{9}$, respectively. $\mathrm{T}_{10}$ produced highest $19.22 \mathrm{q} \mathrm{ha}^{-1}$ followed by $\mathrm{T}_{9}$ with $19.04 \mathrm{q} \mathrm{ha}^{-1}$ seed cotton yield. Therefore, considering plant pigments and both yields $\mathrm{T}_{9}$ can be recommended for growing of Bt cotton under rainfed condition. 


\section{References}

Arnon, D.I. 1975. Copper enzymes in isolated chloroplasts, polyphenol-oxidase in Beta vulgaris. Plant Physiol. 24: 1-15.

Bharambe, P.R. 2010. Integrated inputs management for productivity of $\mathrm{Bt}$ cotton "Proceedings of National symposium on Bt cotton: Opportunities and prospects," November 17-19, 2009. Central Institute for Cotton Research, Nagpur, 22-34.

CCI, 2011. Cotton Corporation of India Ltd. Mumbai, Government of India. www.cotcrop.gov.in/statistics.aspx\#area

Chimmad V.P., Panchal, Y.C., Chimmad, B.V. and Basarkar P.W 1997. Leaf reddening in cotton genotypes Role of chlorophylls, caratenoids and specific leaf weight. Karnataka J. Agric. Sci. 11(3): 651-620.

Gurao, B., Deshpande, R.M. and Sarika, V. 2006. Nutrient management studies in deshi cotton. J. of soils and crops. 76:222-226.

Hiscox, J.D., Israelstam G.F. 1979. A method for the extraction of chlorophyll from leaf tissue without maceration. Canadian Journal of Botany. 57:13321334.

Jadhao, J.G., Jadhao, S.D., Ghodpage R.M. and Ingole, A.S. 2004. Effect of different chemical sprays on reddening and morphological characters. PKV. Res J.28 (2): 225-228.

Jayalatitha K. and Narayanan A. 1996.
Growth and mineral composition of magnesium deficient cotton plants grown in solution culture Ann. Plant Physio. 10(1): 35-40.

Koleva, S D., Edreva, A., Velikova, V. and Gural A. 2005. Effect of reddening of cotton ( $G$. hirsutum L.) leaves on the ulterastructure of mesophyll cells. Photosynthetica, 43(2): 313-316.

Panse, V.G. and Sukhatme P.V. 1967. "Statistical Method for Agricultural Workers", ICAR Publication, New Delhi. 145-148.

Patil, U.D. and Malewar, G.V., 1994. Yield and chlorophyll content of cotton as influenced by micronutrient spray. Journal of Cotton Research and Development, 8, pp.189-192.

Perumal N. K. and Subramaniam, S. 1979. A note on the reddening of leaves in cotton. Science and culture, 45(2):72.

Ramalakshmi, A. and Anthoni Raj S. 2008. Effect of inoculation of biofertilizers on cotton growth and yield. J. Soils and Crops. 18(2): 273-278.

Rao, S. and Janawade A.D. 2006. Studies on integrated nutrient management in irrigated hybrid cotton, J. Cotton Res. Dev. 20(2) 212-215.

Thimmaiah, S. K. 2004. Standard Methods of Biochemical Analysis. Kalyani Publishers, Ludhiana, Pp. 50-52.

Zade, V.R. and Dhopte, A.M. 1987. Anatomy and pigment analysis of red leaf in cotton. PKV Res. J. 11(2): 107-111.

\section{How to cite this article:}

Byale, N.A., V.D. Patil and Nandede, B.M. 2017. Effect of Nutrient Combinations on Plant Pigments and Yield of Bt Cotton Under Rainfed Condition. Int.J.Curr.Microbiol.App.Sci. 6(11): 500-505. doi: https://doi.org/10.20546/ijcmas.2017.611.060 